\title{
BIOSYNTHESIS OF $\triangle$-AMINOLEVULINATE IN GREENING BARLEY LEAVES. IX. STRUCTURE OF THE SUBSTRATE, MODE OF GABACULINE INHIBITION, AND THE CATALYTIC MECHANISM OF GLUTAMATE 1-SEMIALDEHYDE AMINOTRANSFERASE
}

by

\author{
J. KENNETH HOOBER ${ }^{1,3)}$, ALBERT KAHN ${ }^{2)}$, DAVID E. ASH ${ }^{1)}$, SIMON GOUGH ${ }^{3)}$ \\ and C. GAMINI KANNANGARA ${ }^{3)}$ \\ 1) Department of Biochemistry, Temple University School of Medicine, \\ Philadelphia, PA 19140, USA \\ ${ }^{2)}$ Institute of Genetics, University of Copenhagen, \\ Øster Farimagsgade 2A, DK-1353 Copenhagen K \\ 3) Department of Physiology, Carlsberg Laboratory, \\ Gamle Carlsberg Vej 10, DK-2500 Copenhagen Valby
}

Keywords: Chlorophyll synthesis, NMR spectroscopy, 4,5-dioxovalerate, levulinate

Glutamic acid 1-semialdehyde hydrochloride was synthesized and purified. Its prior structural characterization was extended and confirmed by 'H NMR spectroscopy and chemical analyses. In aqueous solution at $\mathrm{pH} 1$ to 2 glutamic acid 1-semialdehyde exists in a stable hydrated form, but at $\mathrm{pH} 8.0$ it has a half-life of 3 to 4 min. Spontaneous degradation of the material at $\mathrm{pH} 8.0$ generated some undefined condensation products, but coincidentally a significant amount isomerized to 5 -aminolevulinate. At pH 6.8 to 7.0 , glutamate 1-semialdehyde is sufficiently stable to permit routine and reproducible assay for glutamate 1-semialdehyde aminotransferase activity. Only about $20 \%$ of the enzyme extracted from chloroplasts was sensitive to inactivation by gabaculine with no pretreatment. However, when the enzyme was exposed to 5-aminolevulinate, levulinate or 4,5-dioxovalerate in the absence of glutamate 1 -semialdehyde, it was completely inactivated by gabaculine; 4,6 -dioxoheptanoate had no effect on the enzyme. These results lead to the hypothesis that the aminotransferase exists in the chloroplast in a complex with pyridoxamine phosphate, which must be converted to the pyridoxal form before it can form a stable adduct with gabaculine. We propose that the enzyme catalyzes the conversion of glutamate 1-semialdehyde to 5 -aminolevulinate via 4,5 -diaminovalerate.

\section{INTRODUCTION}

5-Aminolevulinate, the biosynthetic precursor of porphyrins and chlorophylls, is synthesized from glutamate in plants and numerous bacterial species $(7,9,13,19,21,31,32)$. In the first step of this pathway, glutamate is esterified to tRNA ${ }^{\text {Glu }}$ by glutamic acid-tRNA ligase, which also provides glutamyl-tRNA for protein synthesis $(4,14,26)$. Glutamyl-tRNA then is reduced in an NADPH-requiring reaction. The 
dehydrogenase that catalyzes this reaction is strongly inhibited by low concentrations of hemin $(10,31)$, which suggests that this step is the site of feedback control of porphyrin synthesis. The product of this second reaction is glutamate 1-semialdehyde $(8,15,19)$. Finally, 5aminolevulinate is formed from glutamate 1semialdehyde by an isomerization that is catalyzed by an aminotransferase $(12,13,30)$.

Glutamic acid 1-semialdehyde was previously synthesized chemically and characterized by IR spectroscopy and, as the diethylacetal derivative, by NMR and mass spectroscopy $(8,15)$. The chemically synthesized product is identical to the biosynthetic intermediate isolated from barley seedlings treated with gabaculine (15). However, because of its instability, doubt regarding the existence of glutamate 1-semialdehyde as an intermediate in the pathway to 5 -aminolevulinate was expressed $(11,23)$. We have again purified and carefully reexamined the properties of the compound prepared in this laboratory that function as substrate for the enzymatic conversion to 5-aminolevulinate. In this report we provide further evidence that glutamic acid 1-semialdehyde is indeed the product of the chemical synthesis and is a precursor of 5-aminolevulinate. Glutamate 1semialdehyde aminotransferase has been partially purified, and we describe improved assay conditions for the characterization of this enzyme. Furthermore, we have characterized the interaction of the aminotransferase with gabaculine, a powerful inhibitor of chlorophyll synthesis $(6,12,15,21)$.

\section{MATERIALS AND METHODS}

\subsection{Chemicals}

N-Carboxybenzoxy-L-glutamic acid 5-benzyl ester was obtained from Bachem AG, Switzerland,: 3-amino-2,3-dihydrobenzoic acid hydrochloride (gabaculine) was from Fluka AG, Switzerland; palladium powder, deuterium oxide, 99.8 atom \% D, and 3-(trimethylsilyl) tetradeuteropropionate were from AldrichChemie, W. Germany; phosphorus pentachloride and plastic-backed silica gel 60 TLC sheets were from Merck, W. Germany; 4,6-dioxohep- tanoic acid was from Calbiochem, San Diego, $\mathrm{CA}$; 5-aminolevulinic acid $\cdot \mathrm{HCl}, 3$-methyl-2benzothiazolone hydrazone and Dowex 50WX8 were from Sigma Chemical Co., St. Louis, $\mathrm{MO}$; and 5 -amino $\left(4-{ }^{14} \mathrm{C}\right)$ levulinic $\mathrm{acid} \cdot \mathrm{HCl}$ was purchased from Amersham Denmark ApS. 4,5-Dioxovaleric acid was a generous gift from D. Dörnemann, Philipps-Universität, Marburg/Lahn, W. Germany.

\subsection{Synthesis and purification of glutamic acid 1-semialdehyde}

Glutamic acid 1-semialdehyde was synthesized as described previously (15), except that hydrogenation was allowed to proceed in ether for only $2 \mathrm{hr}$ in a glass cylinder with a sintered glass base. $\mathrm{H}_{2}$ gas, introduced from below the cylinder and dispersed by the sintered glass disc, maintained the palladium catalyst in suspension. Glutamic acid 1-semialdehyde was extracted with water, lyophilized and washed with ice-cold ether. Glutamic acid 1-semialdehyde $\cdot \mathrm{HCl}$ constituted 1 to $2 \%$ and glutamic acid $\cdot \mathrm{HCl}$ about $75 \%$ of this material by weight, while proline was among the other contaminants. When stored dry at $-20^{\circ} \mathrm{C}$, the material showed no loss of substrate for glutamate 1semialdehyde aminotransferase over a period of 12 months. Aqueous solutions $(17 \mathrm{mg} / \mathrm{ml})$ at $\mathrm{pH}$ 1 to 2 were stable for at least 5 months at $4{ }^{\circ} \mathrm{C}$ and were the source of substrate for most enzyme assays.

To purify glutamic acid 1-semialdehyde, the material was dissolved in water and applied to a column $(1 \times 30 \mathrm{~cm})$ of Dowex $50 \mathrm{~W}-\mathrm{X} 8\left(\mathrm{Na}^{+}-\right.$ form). During application of the sample the $\mathrm{pH}$ of the eluant dropped to below 2.5. The column was then washed with $\mathrm{Na}$ citrate $\left(0.2 \mathrm{M}-\mathrm{Na}^{+}\right), \mathrm{pH}$ 3.6, until glutamate was completely removed from the column. Subsequently, glutamate 1semialdehyde was eluted with $\mathrm{Na}$ citrate $(0.2$ $\mathrm{M}-\mathrm{Na}^{+}$), $\mathrm{pH}$ 4.2. Ninhydrin-reactive material was determined by spotting $5 \mu$ aliquots of effluent fractions onto filter paper and spraying with ninhydrin solution. Glutamate 1-semialdehyde was detected in fractions by incubating an aliquot with partially purified glutamate 1 -semialdehyde aminotransferase and measuring the 
production of 5-aminolevulinate (see section 2.4).

Fractions containing glutamate 1-semialdehyde were pooled, acidified to $\mathrm{pH} 2$ with $\mathrm{HCl}$ and applied to a column $(1 \times 15 \mathrm{~cm})$ of Dowex $50 \mathrm{~W}-\mathrm{X} 8\left(\mathrm{H}^{+}\right.$-form). The column was washed with $50 \mathrm{~mm}-\mathrm{HCl}$ to eliminate citrate and then with $500 \mathrm{~mm}-\mathrm{HCl}$. Elution of glutamic acid 1-semialdehyde was detected by reaction with 3-methyl-2-benzothiazolone hydrazone (see section 2.6) and by enzymatic conversion to 5 -aminolevulinate. Fractions containing active material were pooled and lyophilized.

\subsection{Preparation of glutamate 1-semialdehyde aminotransferase}

Most experiments were performed with enzyme partially purified by passing chloroplast stroma through columns of Sephacryl S-300, Cibacron blue-Sepharose, Procion red-agarose and chlorophyllin-Sepharose as described previously $(14,30)$. Because this preparation contained porphobilinogen synthase and porphobilinogen deaminase, assays for the formation of 5 -aminolevulinate included $10 \mathrm{~mm}$-levulinate to block utilization of the product. Some experiments were repeated with enzyme that had been purified further with a column $(2 \times 80 \mathrm{~cm})$ of Sephacryl S-200, which resolved the aminotransferase from the other two enzymes.

\subsection{Assay of glutamate 1-semialdehyde aminotransferase}

Each assay mixture $(1.0 \mathrm{ml})$ contained 0.1 M-Na 2-(N-morpholino)ethanesulfonate- $0.1 \mathrm{M}$ Na phosphate, $\mathrm{pH} 6.8,10 \mathrm{~mm}$-levulinate, partially purified enzyme (100 to $500 \mu \mathrm{g}$ protein) and 10 to $50 \mu \mathrm{M}$-glutamate 1 -semialdehyde. The substrate was added last, and the mixtures were then incubated for various times at $28{ }^{\circ} \mathrm{C}$. Reactions were terminated by adding $25 \mu \mathrm{l}$ of $70 \%$ perchloric acid, and the precipitated protein was removed by centrifugation. The supernatants were transferred into graduated tubes, $200 \mu \mathrm{l}$ of $1 \mathrm{M}$-Na acetate, $\mathrm{pH} 4.8$, were added to each sample and the $\mathrm{pH}$ was adjusted to $4.6 \pm 0.1$ with $\mathrm{NaOH}$. To each tube, $100 \mu \mathrm{l}$ of acetylacetone were added before heating for 20 min in a boiling water bath to produce the 5 -aminolevulinate pyrrole. The tubes were then cooled to room temperature and the volume of liquid per tube adjusted to $1.5 \mathrm{ml}$ with water before mixing with $1.5 \mathrm{ml}$ of modified Ehrlich's reagent (20). Twenty minutes later absorption spectra were recorded from 450 to $650 \mathrm{~nm}$. An assay without protein and substrate served as a reference for spectrophotometry. An extinction coefficient at $553 \mathrm{~nm}$ of $601 \cdot \mathrm{mmole}^{-1}$ for a $1-\mathrm{cm}$ light path was determined with 5-aminolevulinic acid $\cdot \mathrm{HCl}$ and used for calculation of amounts of this product formed in the assays. At $\mathrm{pH} 4.6$ the nonenzymatic conversion of glutamate 1semialdehyde to 5-aminolevulinate during pyrrole formation is negligible, since zero-time controls gave virtually no Ehrlich's reaction. The previously reported positive reaction for glutamate 1-semialdehyde $(12,15)$ was largely due to nonenzymatic production of 5aminolevulinate prior to and during pyrrole formation at $\mathrm{pH} 6.9$.

For the determination of enzymatic formation of 5-aminolevulinate, the amount of product formed in control assays without enzyme was subtracted from that formed in assays with enzyme. Glutamate 1 -semialdehyde concentrations in stock solutions were estimated indirectly from the amount of 5-aminolevulinate produced by enzymatic catalysis with 500 $\mu \mathrm{g}$ or more of crude enzyme protein in reactions that went to completion in under $10 \mathrm{~min}$ at $\mathrm{pH}$ 6.8 at $28^{\circ} \mathrm{C}$.

Formation of uroporphyrin from glutamate 1-semialdehyde or 5-aminolevulinate took place in $0.1 \mathrm{M}$-Tricine- $\mathrm{NaOH}, \mathrm{pH} 8.2$ without levulinate. After reactions were terminated with perchloric acid, samples were exposed to nearUV light to enhance oxidation of uroporphyrinogen to the fluorescent uroporphyrin.

\subsection{Proton NMR spectra}

Spectra were obtained at $300 \mathrm{MHz}$ on a Bruker WM 300 wide bore spectrometer. Spectra were recorded at ambient temperature (ca. $20^{\circ} \mathrm{C}$ ) with a $60^{\circ}$ pulse angle $(10 \mu \mathrm{sec})$, a 6 -sec recycle time, and a spectral width of $\pm 1500 \mathrm{~Hz}$ 
from the carrier with quadrature phase detection. Samples were dissolved in 99.8 atom \% deuterium oxide immediately prior to data acquisition. For solutions of glutamic acid 1-semialdehyde, the $\mathrm{pD}$ (uncorrected meter reading) was 1.84. Chemical shifts are reported relative to external 3-(trimethylsilyl)tetradeuteropropionate. The spectra ( $16 \mathrm{~K}$ data points) were processed with a $0.2 \mathrm{~Hz}$ line-broadening function.

\subsection{Assay of aldehyde function}

The assay was adapted from the procedure described in (25). Twenty $\mu$ l of solutions of glutamate 1-semialdehyde were mixed with 100 $\mu \mathrm{l}$ of $0.4 \%$ 3-methyl-2-benzothiazolone hydrazone. After $30 \mathrm{~min}$ at room temperature, $250 \mu \mathrm{l}$ of $0.2 \% \mathrm{FeCl}_{3}$, freshly diluted from a $20 \%$ stock solution, were added. Color was allowed to develop for $30 \mathrm{~min}$ before the sample was diluted with $500 \mu$ l of acetone and the absorbance measured at $650 \mathrm{~nm}$. Absorbance was linear with concentration of glutamate 1 -semialdehyde up to 1.8 .

\subsection{Other methods}

Thin layer chromatography was performed on silica gel 60 sheets with n-butanol-acetic acid-water (60:20:20, v/v/v) as solvent. Protein was estimated by the Lowry procedure (18). Amino acid analysis was performed with a standard single-column analyzer and a lithium citrate buffer system (Pierce Chemical Co., Rockford, IL).

\section{RESULTS}

\subsection{Properties of glutamic acid 1-semialdehyde}

Elution of glutamic acid 1-semialdehyde from Dowex $50 \mathrm{~W}-\mathrm{X} 8$ columns was detected by its reaction with the aldehyde-specific reagent 3methyl-2-benzothiazolone hydrazone (25), reaction with ninhydrin, and enzymatic conversion to 5-aminolevulinate. Purified glutamic acid 1-semialdehyde migrated as a single, ninhydrin-positive component during thin-layer

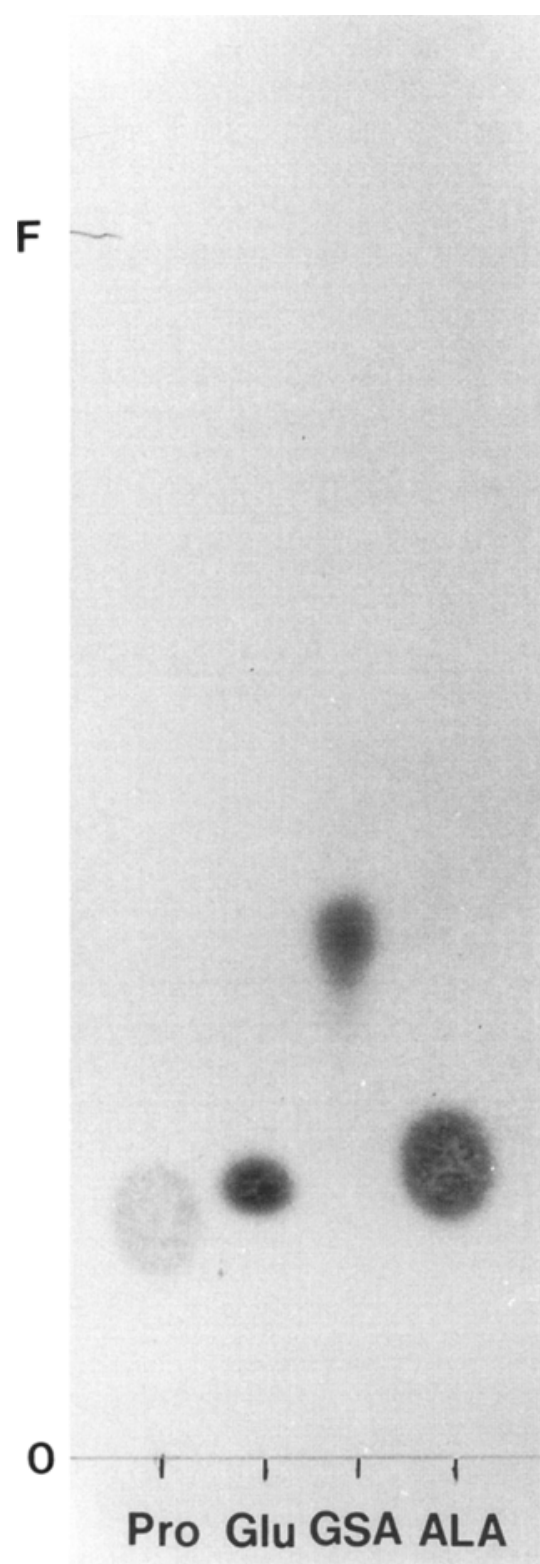

Figure 1. Migration of glutamic acid 1-semialdehyde (GSA) relative to proline (Pro), glutamic acid (Glu) and 5-aminolevulinic acid (ALA) during silica gel thin-layer chromatography. $\mathrm{O}=$ origin; $\mathrm{F}=$ solvent front.

chromatography on silica gel with an $R_{f}=0.43$ (Figure 1). A single ninhydrin-positive component, with a retention time similar to that of isoleucine, was detected with an amino acid 


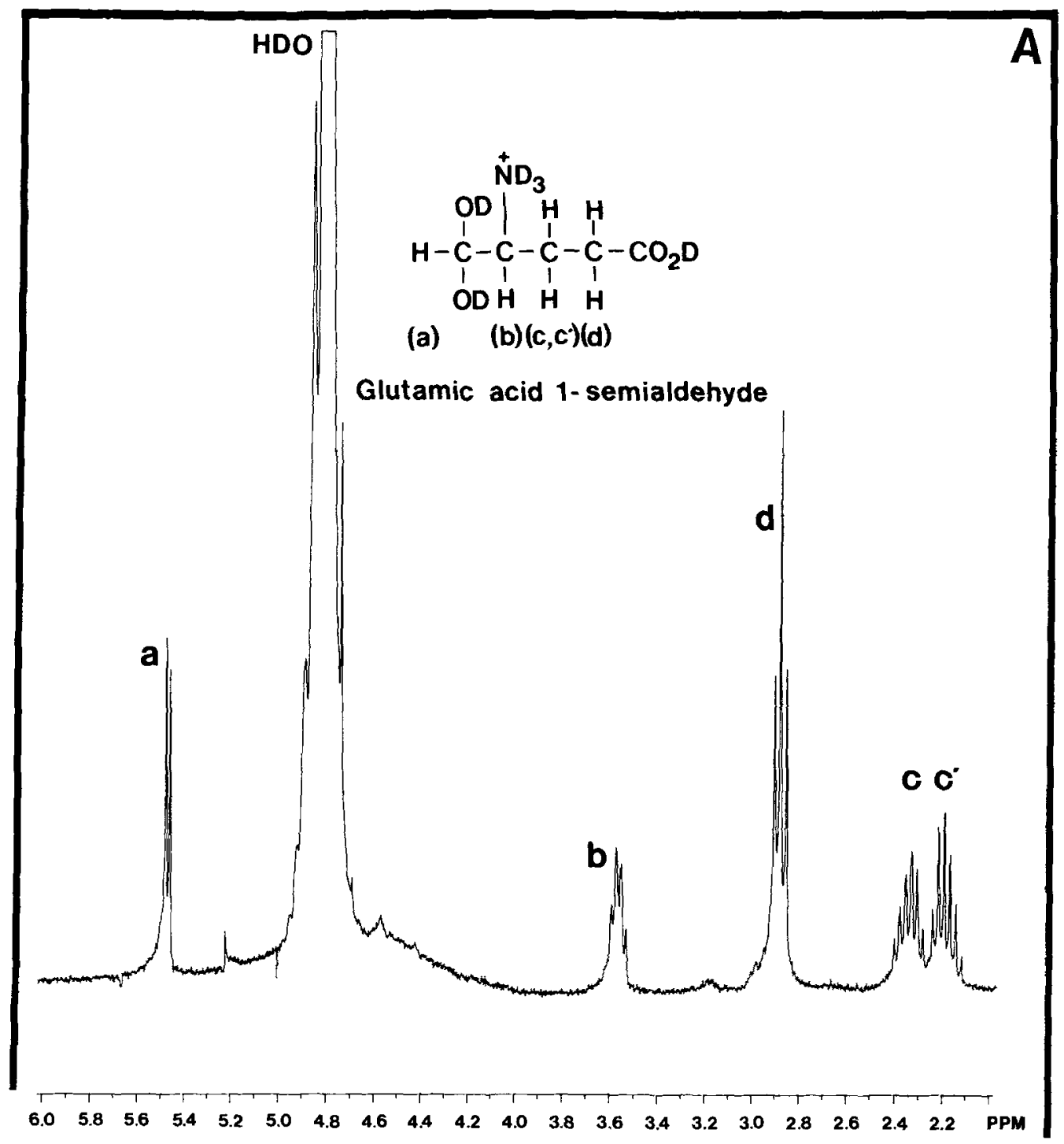

Figure 2A. Proton NMR spectrum of glutamic acid 1-semialdehyde in $\mathrm{D}_{2} \mathrm{O}$.

analyzer. Glutamic acid 1-semialdehyde was well resolved from 5-aminolevulinic acid, which migrated more slowly on thin-layer silica gel sheets and in the amino acid analyzer. After elution with $\mathrm{HCl}$ from a Dowex 50W-X8 column (see section 2.2 ), the only contaminant detected in the sample was $\mathrm{NaCl}$, which was introduced during chromatography.

\subsection{Structure of glutamate 1-semialdehyde}

The ${ }^{1} \mathrm{H}$ NMR spectrum for glutamic acid 1 -semialdehyde in $\mathrm{D}_{2} \mathrm{O}$ is shown in Figure 2A. Since the concentration of the compound in the sample was not known, for interpretation of the integrated intensities for this spectrum the resonance for the methylene protons on carbon 4 $(\delta 2.89)$ were assigned a value corresponding to 


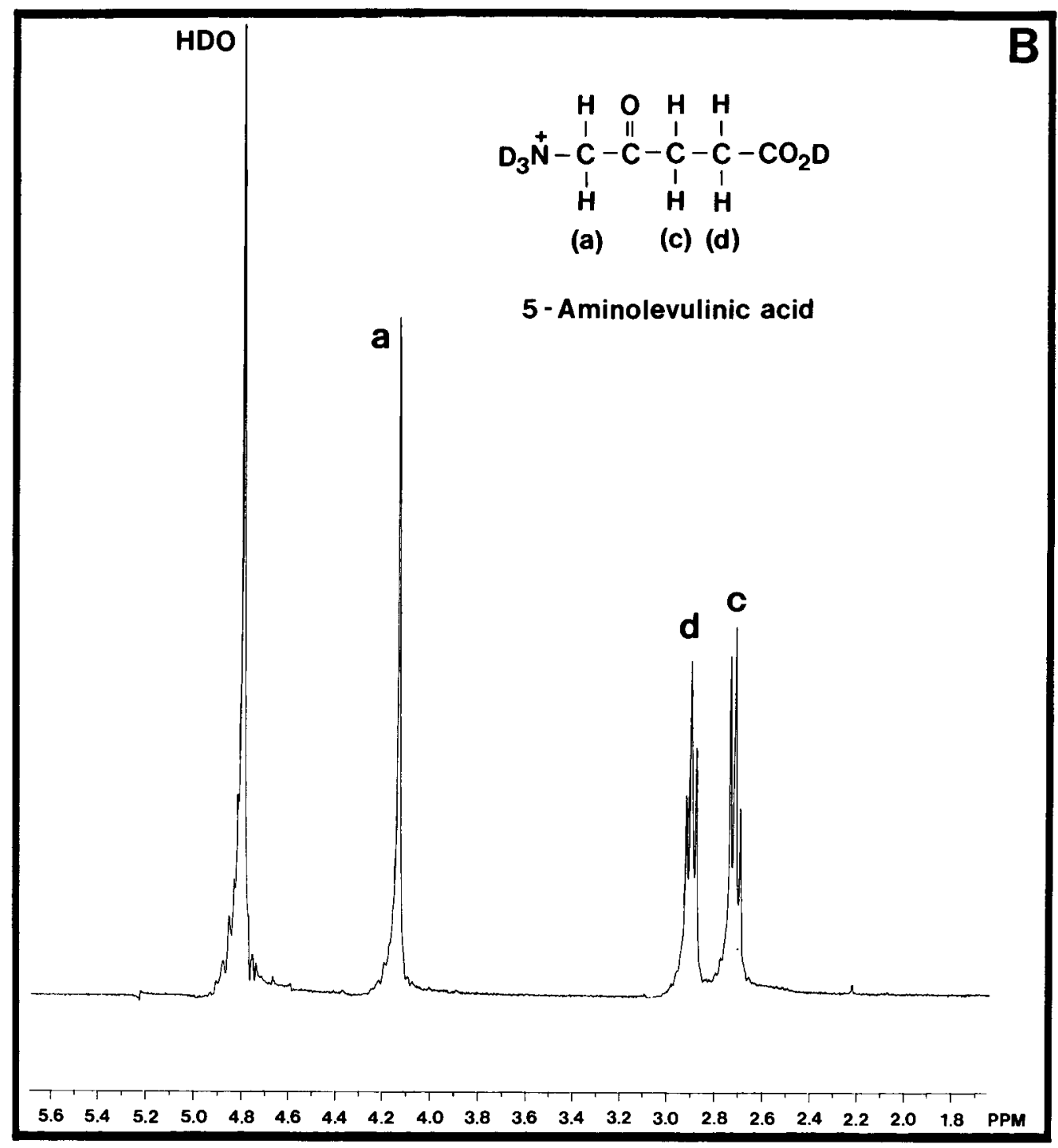

Figure 2B. Proton NMR spectrum of 5-aminolevulinic acid in $\mathrm{D}_{2} \mathrm{O}$.

2 protons. On the basis of this assumption the following assignments can be made: $\delta 2.18(1 \mathrm{H}$, $\left.\mathrm{m},{ }^{-} \mathrm{OOC}-\mathrm{CH}_{2}-\mathrm{CH} H-\right), \delta 2.35\left(1 \mathrm{H}, \mathrm{m},{ }^{-O O C}-\right.$ $\left.\mathrm{CH}_{2}-\mathrm{CH} \underline{H}-\right), \delta 2.89\left(2 \mathrm{H}, \mathrm{t}, \mathrm{J}=7.6 \mathrm{~Hz}\right.$, ${ }^{-O O C}$ $\left.\mathrm{C}_{2_{2}}^{-}\right), \delta 3.57\left(1 \mathrm{H}, \mathrm{m}\right.$, = $\left.\mathrm{CHND}_{3}^{+}\right)$, and $\delta 5.48$ $\left(1 \mathrm{H}, \mathrm{d}, \mathrm{J}=4.9 \mathrm{~Hz},-\mathrm{CH}(\mathrm{OD})_{2}\right)$. The doublet at $\delta 5.48$ corresponded to the resonance of the proton in hydrated amino aldehydes $(1,17)$. The region between 8 and 10 ppm did not exhibit any detectable resonance attributable to the proton of a free aldehyde. The 'H NMR spectra of 5-aminolevulinic acid (Figure 2B) and glutamic acid (Figure 2C) were distinctly different from that of glutamic acid 1-semialdehyde. Integration of the intensities of the resonances in the spectrum of glutamic acid 1-semialdehyde gave the expected value of one proton for the doublet at $\delta 5.48$ (Table I). Two separate batches of glutamic acid 1-semialdehyde gave identical spectra. Furthermore, the other non-exchange- 


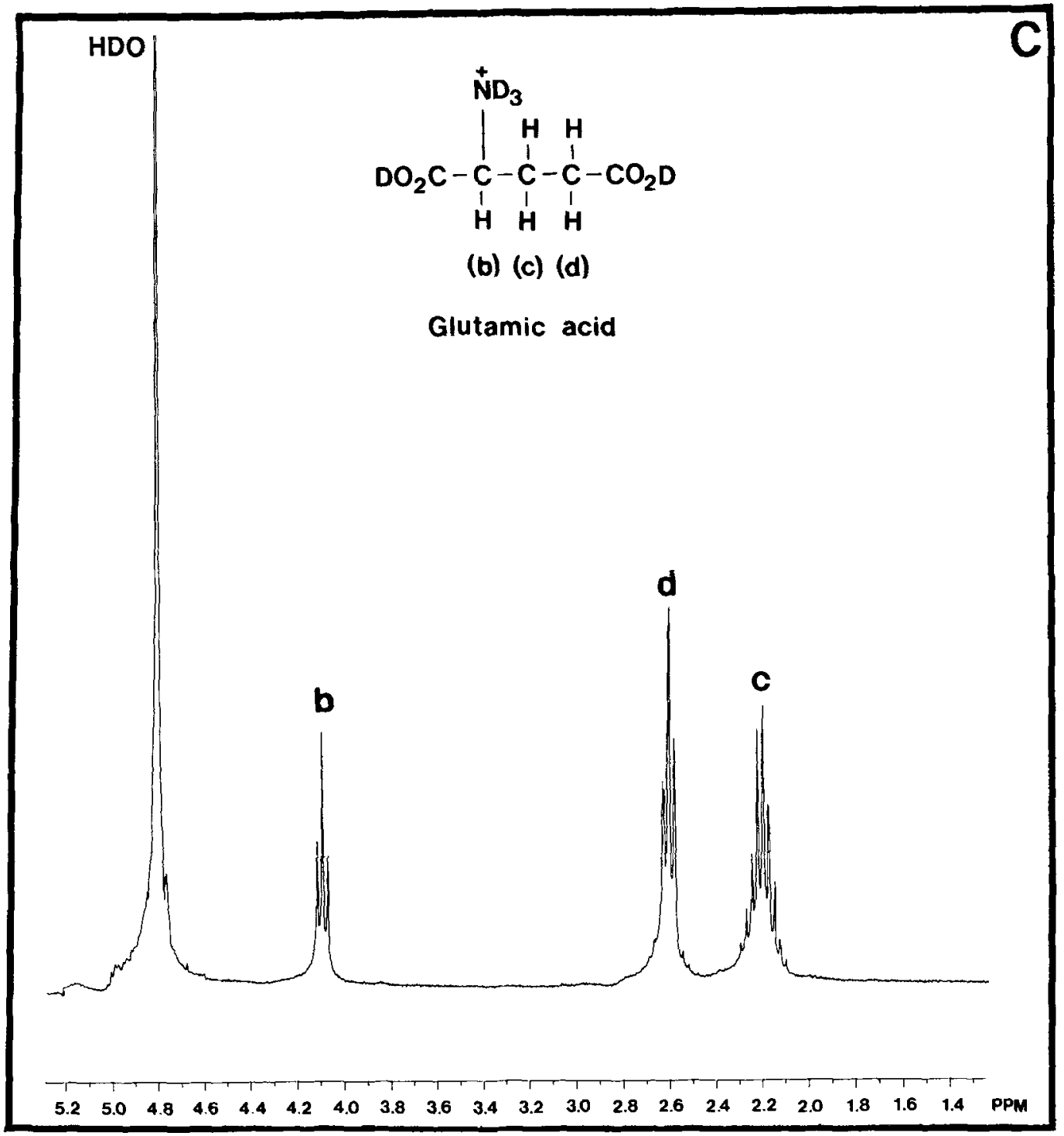

Figure 2C. Proton NMR spectrum of glutamic acid in $\mathrm{D}_{2} \mathrm{O}$.

able protons in the semialdehyde, glutamic acid and 5-aminolevulinic acid also gave values close to those expected.

\subsection{Stability of glutamate 1-semialdehyde}

Glutamic acid 1-semialdehyde in acid solutions $(\mathrm{pH} 1-2)$ is relatively stable, as reported previously (15). When the $\mathrm{pH}$ is raised, however, decay of the compound occurs at an increasingly rapid rate. As Figure 3 illustrates, at $\mathrm{pH} 8.0$ the aldehyde function as determined with 3-methyl2-benzothiazolone hydrazone (see 2.6) decayed to $35-40 \%$ of the original amount and then remained constant. Proton NMR analysis of such a degraded sample detected a resonance of an aldehydic proton at $\delta 8.5$, but no amino group was available in this material for reaction 
Table I. Integration values from proton NMR spectra.

\begin{tabular}{clll}
\hline Compound & $\begin{array}{l}\text { Proton } \\
\text { designation }\end{array}$ & ppm & Integral \\
\hline A. Glutamic acid & a & $5.48(\mathrm{~d})$ & 0.89 \\
1-semialdehyde & b & $3.57(\mathrm{~m})$ & 0.98 \\
& c & $2.35(\mathrm{~m})$ & 0.90 \\
& c' & $2.18(\mathrm{~m})$ & 0.95 \\
B. 5-Aminolevulinic & d & $2.89(\mathrm{t})$ & $2.00^{+}$ \\
acid & a & $4.15(\mathrm{~s})$ & 1.6 \\
& c & $2.71(\mathrm{t})$ & 1.7 \\
C. Glutamic acid & d & $2.90(\mathrm{t})$ & $2.00^{+}$ \\
& b & $4.16(\mathrm{t})$ & 0.90 \\
& $\mathrm{c}$ & $2.20(\mathrm{~m})$ & 2.00 \\
& d & $2.65(\mathrm{t})$ & $2.00^{+}$ \\
\hline
\end{tabular}

${ }^{8}$ Letter designations for protons are as indicated in Figures 2A, 2B, 2C.

+ The integration values for the methylene protons next to the carboxyl group ( $\mathrm{C}-4$ in glutamic acid 1 -semialdehyde) were arbitrarily set to 2.0 .

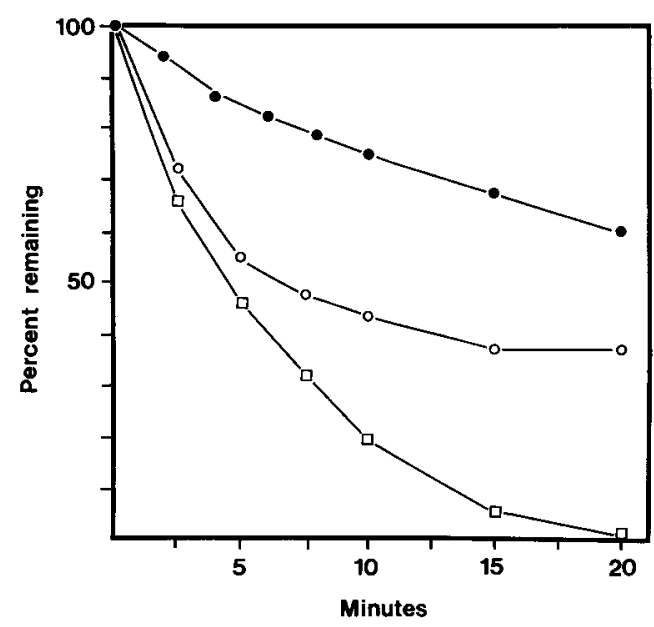

Figure 3. Loss of glutamate 1-semialdehyde at $28{ }^{\circ} \mathrm{C}$ determined chemically at $\mathrm{pH} 6.8(\bullet)$ and at $\mathrm{pH} 8.0(\mathrm{O})$ and determined enzymically at $\mathrm{pH} 8.0(\square)$. Using an initial concentration of $50 \mu \mathrm{M}$-glutamate 1-semialdehyde relative aldehyde contents were determined chemically as given in 2.6 or enzymically as given in 2.4 .

with ninhydrin. The $\mathrm{t}_{1 / 2}$ for the decay at $\mathrm{pH} 8.0$ to this plateau was $3 \mathrm{~min}$. A short half-life for glutamate 1-semialdehyde after exposure to $\mathrm{pH}$ 8.0 was also found using an amino acid analyzer. An increase in absorbance of a solution of glutamate 1-semialdehyde at 345 and $274 \mathrm{~nm}$ during decay suggested that condensation products were formed.

Figure 3 also shows that the amount of glutamate 1-semialdehyde detected by enzymatic

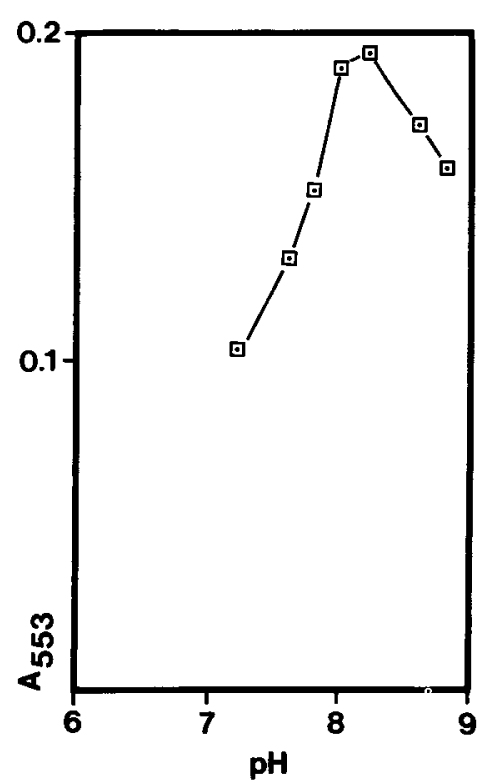

Figure 4. The $\mathrm{pH}$ dependence of the nonenzymatic formation of 5-aminolevulinate from glutamate 1 semialdehyde. Portions of a fresh solution of $25 \mu \mathrm{M}$ glutamate 1-semialdehyde in $0.1 \mathrm{M}-\mathrm{Na}$ phosphate, $\mathrm{pH}$ 7.2 , were adjusted to the indicated $\mathrm{pH}$ with $\mathrm{Na}_{3} \mathrm{PO}_{4}$ and incubated at room temperature for $75 \mathrm{~min}$. 
production of 5-aminolevulinate decayed with a $\mathrm{t}_{1 / 2}$ of about $4 \mathrm{~min}$ at $\mathrm{pH}$ 8.0. Loss of substrate as measured using enzyme was complete in 20 min, even though residual aldehyde as determined chemically remained.

The rate of loss of glutamate 1-semialdehyde, as assayed chemically for aldehyde content, was much slower at pH 6.8 (Figure 3). About 15 min was required at $\mathrm{pH} 6.8$ to achieve the same loss as in $3 \mathrm{~min}$ at $\mathrm{pH} 8.0$.

\subsection{Nonenzymatic conversion of glutamate \\ 1-semialdehyde to 5-aminolevulinate}

A surprisingly high rate of nonenzymatic production of 5-aminolevulinate occurred in solutions of glutamate 1-semialdehyde during incubation at $\mathrm{pH} 8$. Figure 4 shows the strong $\mathrm{pH}$ dependence of this reaction between 7.2 and 8.2. The fall in the curve above $\mathrm{pH} 8.2$ may be due in part to instability of 5-aminolevulinate in alkaline solutions. Because spontaneous formation of 5-aminolevulinate interferes with studies of the enzymatic reaction, we examined several parameters more closely. As shown by the timecourse in Figure 5, the reaction was not complete at $\mathrm{pH} 7.2$ after $1 \mathrm{hr}$. In another experiment, even after $2 \mathrm{hr}$ the reaction produced only $62 \%$

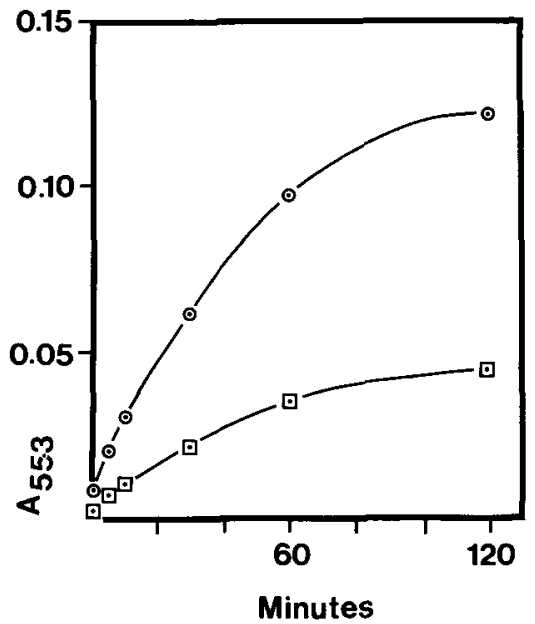

Figure 5. Time-course at $28{ }^{\circ} \mathrm{C}$ for nonenzymatic formation of 5-aminolevulinate at $\mathrm{pH} 7.2$ with initial concentrations of glutamate 1-semialdehyde of $25 \mu \mathrm{M}$ (口) and $50 \mu \mathrm{M}(\odot)$. as much product as at $\mathrm{pH} 8.2$. After $2 \mathrm{hr}$ at $\mathrm{pH}$ $7.2,50 \mathrm{nmol}$ and $25 \mathrm{nmol}$ of glutamate 1 -semialdehyde produced $6 \mathrm{nmoles}$ and 2.2 nmoles of 5-aminolevulinate, respectively.

This apparent lack of linearity of product formed with initial concentration of glutamate 1 -semialdehyde was examined by studying the concentration dependence of the reaction over a wider range. Figure 6 shows that at all concentrations tested, the reaction was more rapid at $\mathrm{pH}$ 8.2 than at $\mathrm{pH} 6.8$. At both $\mathrm{pH}$ values the reaction was not strictly linear with concentration of glutamate 1-semialdehyde, particularly at the lower concentrations.

That 5-aminolevulinate was indeed made in this nonenzymatic reaction was verified by coelution of the product from a Dowex 50W-X8 ( $\mathrm{H}^{+}$-form) column with 5 -amino $\left(4-{ }^{14} \mathrm{C}\right)$ levulinate, by co-chromatography with 5-aminolevulinate on silica gel 60 sheets, and by conversion of the product to uroporphyrin as described in 2.4. Reduction of glutamate 1-semialdehyde with $\mathrm{NaBH}_{4}$ destroyed its ability to be converted

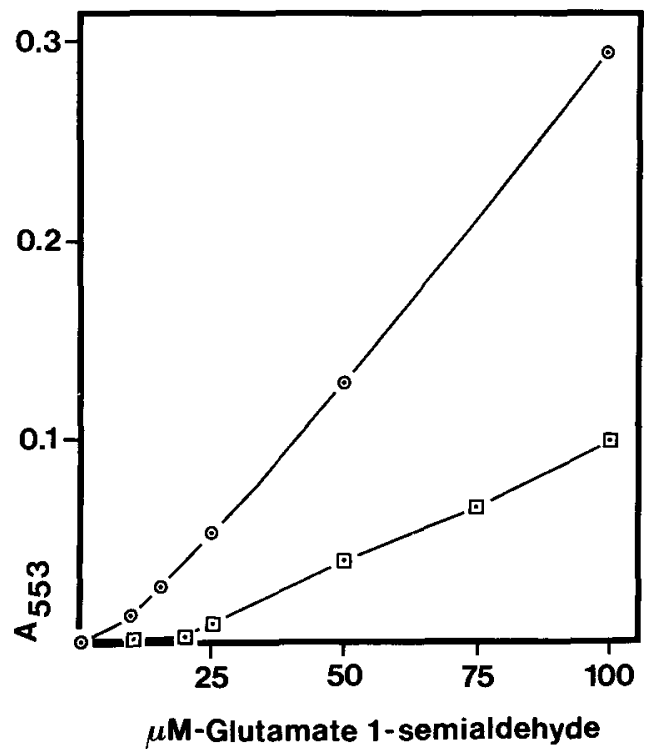

Figure 6. Nonenzymatic formation of 5-aminolevulinate in $10 \mathrm{~min}$ at $28^{\circ} \mathrm{C}$ as a function of the initial concentration of glutamate 1 -semialdehyde in 0.1 M-Na 2-(N-morpholino)ethanesulfonate- $0.1 \mathrm{M}-\mathrm{Na}$ phosphate, pH $6.8(\square)$, and in $0.1 \mathrm{M}$-Tricine- $\mathrm{NaOH}$, pH $8.2(\odot)$. 
to 5-aminolevulinate. The reduced product, presumably the amino alcohol, migrated more slowly on silica gel thin-layer sheets, with an $R_{f}$ $=0.25-0.30$.

\subsection{Development of an assay for glutamate 1-semialdehyde aminotransferase}

Because of the increased stability of glutamate 1-semialdehyde and the much slower rate of nonenzymatic conversion to 5 -aminolevulinate below $\mathrm{pH} 7.2$ than at higher $\mathrm{pH}$, where earlier work $(12,13,15)$ was performed, $\mathrm{pH} 6.8$ buffer was chosen for assays of glutamate 1-semialdehyde aminotransferase. The enzyme was shown earlier to retain significant activity in this $\mathrm{pH}$ range (13). In most experiments unpurified rather than purified glutamic acid 1-semialdehyde was dissolved and used as substrate, because the former was more stable in the solid form and provided more consistent results. Also, the larger amounts of the unpurified material available allowed more experimentation with a single batch and thus direct comparisons within a larger set of data. Samples of purified

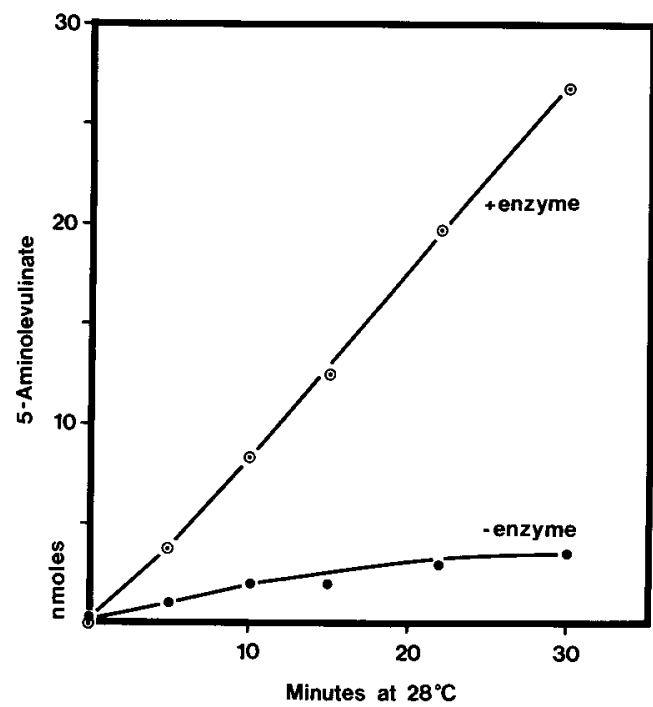

Figure 7. Formation of 5-aminolevulinate from substrate in the presence and absence of glutamate 1-semialdehyde aminotransferase. Incubations were carried out at $28^{\circ} \mathrm{C}$ either with or without $250 \mu \mathrm{g}$ of enzyme protein in $1 \mathrm{ml}$ typical reaction mixtures as described in 3.5 .

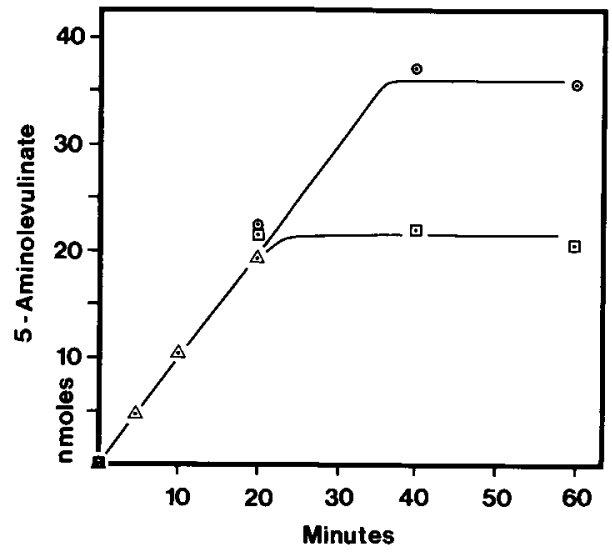

Figure 8. Time course of enzymatic synthesis of 5 aminolevulinate from glutamate 1 -semialdehyde at $\mathrm{pH} 6.8$ with initial concentrations of glutamate 1-semialdehyde of $25 \mu \mathrm{M}(\square), 40 \mu \mathrm{M}(\Delta)$ and $50 \mu \mathrm{M}(\odot)$. The assays contained $250 \mu \mathrm{g}$ protein in $1 \mathrm{ml}$ assay mixtures and incubations were carried out at $28^{\circ} \mathrm{C}$.

glutamic acid 1-semialdehyde in which no contaminating compound other than $\mathrm{NaCl}$ was detected (see sections 2.2 and 3.1) showed the same characteristics in enzymatic assays as unpurified material.

The typical reaction mixture contained 50 $\mu \mathrm{M}$-glutamate 1 -semialdehyde, $250 \mu \mathrm{g}$ of protein, and $10 \mathrm{~mm}$-levulinate in $1.0 \mathrm{ml}$ of 0.1 $\mathrm{M}-\mathrm{Na}$ 2-(N-morpholino)ethanesulfonate- $0.1 \mathrm{M}$ $\mathrm{Na}$ phosphate, $\mathrm{pH}$ 6.8. Under these conditions the enzyme catalysed formation of 5aminolevulinate from glutamate 1-semialdehyde was nearly an order of magnitude faster than the spontaneous conversion of substrate to the product (Figure 7). Addition of glycerol, dithiothreitol or $\mathrm{MgCl}_{2}$ to the assay, which were included in earlier work on this enzyme $(12,13$, 15), had no effect on the activity. Glutamate or proline added to an assay with purified glutamate 1 -semialdehyde did not affect activity. The reaction was allowed to proceed for various periods of time up to an hour. Figure 8 shows that the rate of enzymatic synthesis of 5aminolevulinate was constant for nearly $40 \mathrm{~min}$ under these conditions but ceased abruptly after this time since the substrate was essentially exhausted. With $25 \mu \mathrm{M}$-substrate, the reaction stopped after about $20 \mathrm{~min}$ when a bit more than 


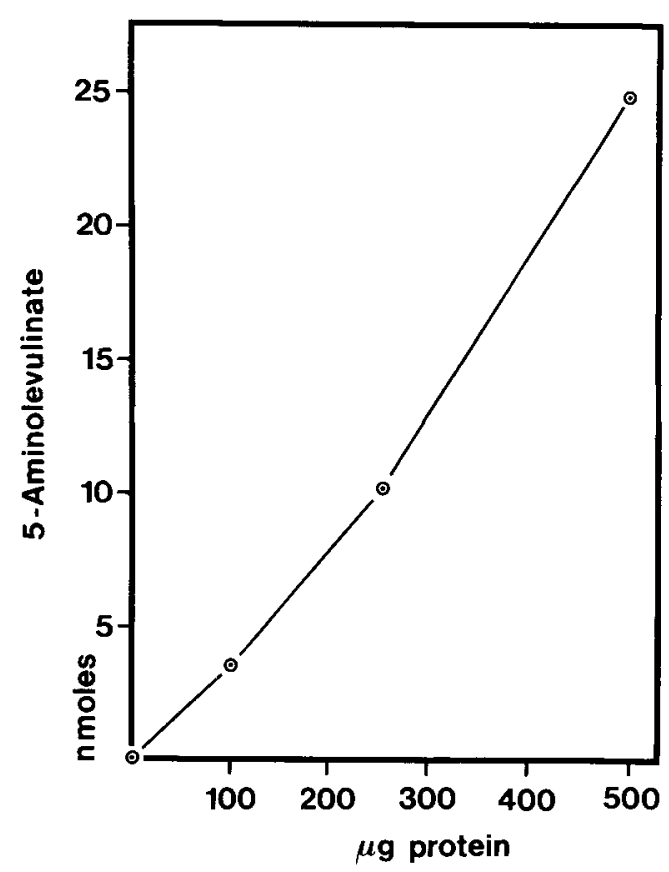

Figure 9. Effect of enzyme concentration on conversion of glutamate 1-semialdehyde $(40 \mu \mathrm{M})$ to 5aminolevulinate at $\mathrm{pH}$ 6.8. Assays were incubated for $10 \mathrm{~min}$ at $28^{\circ} \mathrm{C}$.

half as much product had been formed enzymatically. The rates of the enzymic reactions with initial concentrations of 25,40 and $50 \mu \mathrm{M}$-glutamate 1-semialdehyde were the same, and no diminution in the rate (ca. 1 nmole 5aminolevulinate formed per minute) was observed.

The relation of the rate of the enzymatic reaction with respect to the amount of protein added to the assay mixtures is shown in Figure 9.

\subsection{Characteristics of gabaculine inhibition of glutamate 1-semialdehyde aminotrans- ferase}

The assay system described above was used to determine the effect of gabaculine on the aminotransferase. Figure 10 shows that in the presence of substrate the onset of inhibition by gabaculine was slow and concentration dependent. At gabaculine concentrations of 1 and $2.5 \mu \mathrm{M}$, inhibi-

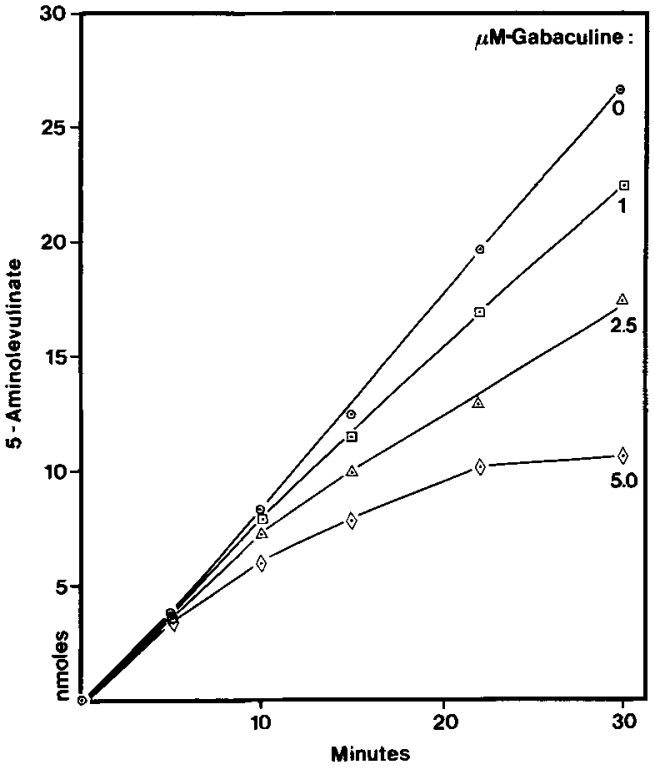

Figure 10. Progressive inactivation of glutamate 1semialdehyde aminotransferase with increasing time in the presence of gabaculine at $\mathrm{pH}$ 6.8. The assays contained $50 \mu \mathrm{M}$-glutamate 1 -semialdehyde, $10 \mathrm{mM}$ levulinate and $250 \mu \mathrm{g}$ protein.

tion remained incomplete up to $30 \mathrm{~min}$, whereas full inhibition was established by $5 \mu \mathrm{M}$-gabaculine after about $20 \mathrm{~min}$ of incubation.

When aminotransferase was first preincubated with gabaculine at $\mathrm{pH} 6.8$ in the presence of $10 \mathrm{~mm}$-levulinate and then substrate added, the enzyme was an order of magnitude more sensitive to gabaculine than when glutamate 1-semialdehyde was presented together with gabaculine and levulinate (Figure 11). Only $0.25 \mu \mathrm{M}$ gabaculine was sufficient to produce $50 \%$ inhibition in $15 \mathrm{~min}$ in the absence of substrate, whereas 3 to $4 \mu \mathrm{M}$-gabaculine was required to produce $50 \%$ inhibition in $15 \mathrm{~min}$ in the presence of $50 \mu \mathrm{M}$-substrate.

Sensitivity of glutamate 1-semialdehyde aminotransferase to gabaculine was dependent upon the presence of a keto compound, such as levulinate, which apparently served as an amino group acceptor. To determine whether gabaculine was interacting with the keto compound or with the enzyme, aminotransferase was incubated with keto compounds, which then were 
Table II. Treatment of glutamate 1-semialdehyde aminotransferase with keto-compounds induces sensitivity to gabaculine. Enzyme in $1.0 \mathrm{ml}$ was preincubated with the various compounds at $\mathrm{pH} 6.8$ for $15 \mathrm{~min}$ at $28{ }^{\circ} \mathrm{C}$ and then passed through a column $(1 \times 8 \mathrm{~cm})$ of Sephadex G-50 to remove the compound. An aliquot of this enzyme was assayed directly for activity, whereas another aliquot was incubated with gabaculine $(10 \mu \mathrm{M})$ at $\mathrm{pH} 6.8$ for $15 \mathrm{~min}$ at $28^{\circ} \mathrm{C}$. The enzyme was again passed through the gel filtration column to remove free gabaculine and then assayed for activity using the typical reaction mixture given in section 3.5. Protein was measured in each case and results are expressed as percent of control specific activity. The MES-phosphate buffer described (section 2.4) was used throughout.

\begin{tabular}{lcc}
\hline Preincubation & Gabaculine treatment & $\begin{array}{c}\text { Percent enzyme } \\
\text { activity remaining }\end{array}$ \\
\hline None & - & 100 \\
& + & $80 \pm 5$ \\
5-Aminolevulinate $(5 \mathrm{mM})$ & - & 97 \\
& + & 4 \\
Levulinate (10 mM) & - & 93 \\
& + & 0 \\
4,5-Dioxovalerate $(1 \mathrm{mM})$ & - & 81 \\
4,6-Dioxoheptanoate $(1 \mathrm{mM})$ & + & 0 \\
Pyruvate $(10 \mathrm{mM})$ & - & 84 \\
\hline
\end{tabular}

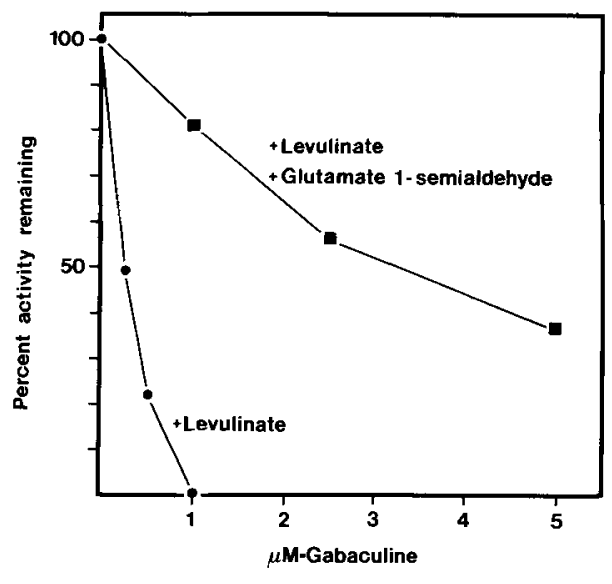

Figure 11. Protection by substrate against inactivation of glutamate 1-semialdehyde aminotransferase by gabaculine in the presence of levulinate. The enzyme (250 $\mu \mathrm{g}$ protein) was preincubated at $\mathrm{pH} 6.8$ with levulinate $(10 \mathrm{~mm})(\bullet)$ and gabaculine $(0.025,0.5$ or $1.0 \mu \mathrm{M})$ for $15 \mathrm{~min}$ at $28^{\circ} \mathrm{C}$ in the absence of substrate. Then substrate $(50 \mu \mathrm{m})$ was added. Reactions were stopped after a further $15 \mathrm{~min}$ at $28{ }^{\circ} \mathrm{C}$. The points show relative enzyme activities, as assayed after preincubation. Enzyme incubated together with substrate, gabaculine and levulinate without preincubation (匚). Relative enzyme activities remaining after $15 \mathrm{~min}$ at $28{ }^{\circ} \mathrm{C}$ were estimated from the slopes, taken between 15 and $22 \mathrm{~min}$, of the curves in Figure 10. separated from the enzyme by gel filtration. The eluted enzyme fraction was then incubated with gabaculine and again subjected to gel filtration to remove gabaculine. As listed in Table II, when the enzyme preparation was incubated first in buffer and then with gabaculine, $80 \pm 5 \%$ of the activity was recovered. However, complete inactivation resulted when the enzyme was preincubated with levulinate or 4,5-dioxovalerate before exposure to gabaculine. Preincubation with 5-aminolevulinate caused nearly all the enzyme to become sensitive to gabaculine, but the extent of inactivation was not affected by 4,6-dioxoheptanoate and only slightly, if at all, by pyruvate.

\section{DISCUSSION}

The present results establish that glutamate l-semialdehyde is a substrate for synthesis of 5-aminolevulinate. Proton NMR spectroscopy showed that at low pH the aldehyde is nearly quantitatively in the hydrated form. Similarly, an aldehydic proton was not detected in the proton NMR spectrum of 4,5-dioxovaleric acid, a compound proposed as another precursor of 5 -aminolevulinate $(5,16)$. Evidence was pre- 


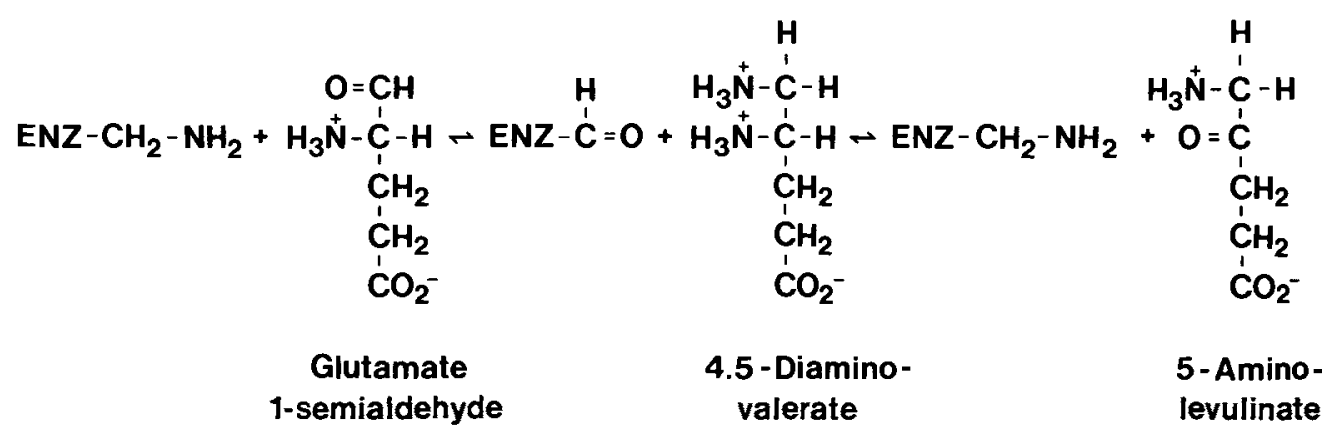

Figure 12. Proposed mechanism for the conversion of glutamate 1-semialdehyde to 5-aminolevulinate by the aminotransferase. The enzyme is represented as pyridoxamine $\left(-\mathrm{CH}_{2}-\mathrm{NH}_{2}\right)$ or pyridoxal $(-\mathrm{CHO})$ forms.

sented that the aldehyde group in 4,5-dioxovaleric acid also exists in the hydrated form (5). In this regard, these compounds are similar to other aldehydes and amino aldehydes $(1,17)$. The separation of the doublet at $\delta 5.48$ from the amino-carbon proton at $\delta 3.57$ in the NMR spectrum of glutamic acid 1-semialdehyde was the same as that reported for leucinal, an analogous compound (1). Since the activity of leucinal and other amino aldehydes as protease inhibitors requires the free aldehyde $(1,17)$, it would be interesting to determine whether hydration affects the substrate properties of glutamate 1-semialdehyde.

The apparent high efficiency of the aminotransferase has revealed the need for a more sensitive assay method to examine the enzymatic parameters of this protein. The enzyme was saturated with concentrations of glutamate 1semialdehyde in the assay below $25 \mu \mathrm{M}$, and no diminution in the rate of conversion to 5aminolevulinate was detected until the reaction had essentially reached completion. Direct determination of the $K_{M}$ value of the aminotransferase for glutamate 1-semialdehyde, therefore, was not possible with the current assay methods.

A double-reciprocal plot of the data represented in Figure 11 suggested that glutamate 1-semialdehyde and gabaculine competed for the same site on the enzyme. Because kinetic parameters of the enzyme could not be determined directly, approximate dissociation constants were calculated by considering gabaculine as "substrate" and glutamate 1-semialdehyde a competitive "inhibitor" of the inactivation reaction. Appar- ent dissociation constants for gabaculine and glutamate 1-semialdehyde were estimated as 0.5 and $3 \mu \mathrm{M}$, respectively. These values, obtained indirectly, should be considered as preliminary estimates for these parameters and must be confirmed by a detailed analysis of the properties of the enzyme. It is obvious that the enzyme is adapted to convert a highly reactive and unstable substrate to 5-aminolevulinate, which is required in large amounts for chlorophyll synthesis during chloroplast development. The $\mathrm{K}_{\mathrm{M}}$ for glutamate:4,5-dioxovalerate transaminase from Chlorella, which catalyzes an alternate reaction for formation of 5-aminolevulinate, is $0.48 \mathrm{mM}$ for glutamate and $2 \mathrm{mM}$ for 4,5-dioxovalerate (22). The $\mathrm{K}_{\mathrm{M}}$ for 4,5-dioxovalerate for transaminases from Clostridium (2) and radish (28) were reported as 0.26 and 0.71 $\mathrm{mM}$, respectively, which are several orders of magnitude greater than that estimated for glutamate 1-semialdehyde with the aminotransferase.

Glutamate 1-semialdehyde aminotransferase may be among the most sensitive enzymes, including 4-aminobutyrate transaminase (24, 29), to inactivation by gabaculine. Inhibition of the former enzyme by aminooxyacetate (13) and by gabaculine suggest that it is a vitamin $\mathbf{B}_{6}$-containing protein. SOPER and MANNING (29) demonstrated that only the pyridoxal phosphate form of transaminases is sensitive to gabaculine. Likewise, sensitivity of glutamate 1-semialdehyde aminotransferase to gabaculine required incubation in the presence of an amino acceptor. The enzyme apparently is extracted 
from the chloroplast largely in the gabaculineinsensitive, pyridoxamine form. The pyridoxal form of the enzyme can be generated by incubating the enzyme with compounds such as levulinate and 4,5-dioxovalerate. Interestingly, these compounds have been used as inhibitors of the next enzyme in the porphyrin biosynthetic pathway, porphobilinogen synthase $(3,27)$, which uses 5-aminolevulinate as substrate. Positive identification of pyridoxamine phosphate as the cofactor in the aminotransferase is a task for the future.

We propose that the mechanism of the reaction catalyzed by glutamate 1-semialdehyde aminotransferase follows the scheme shown in Figure 12. For the enzyme to form 5aminolevulinate, it must first donate the pyridoxamine amino group to glutamate 1-semialdehyde to form the intermediate 4,5-diaminovalerate. Subsequent transfer of the 4-amino group to the enzyme then liberates 5aminolevulinate and regenerates the amino form of the enzyme. We expect that the enzyme should catalyze a reversible reaction, although our results suggest that glutamate 1-semialdehyde is converted essentially quantitatively to 5-aminolevulinate.

In conclusion, we have defined the properties of glutamate 1-semialdehyde aminotransferase with respect to structure of the substrate, suitable conditions for assaying the activity of the enzyme, and the interaction of the enzyme with gabaculine. The basis is now available to begin a detailed study of the kinetic and mechanistic properties of the aminotransferase.

\section{ACKNOWLEDGEMENTS}

We thank Prof. Diter von WeTtSTEIN for critically reading the manuscript, NINA RASMUSSEN for drawing the figures, and BARBARA KELLER for performing the amino acid analyses. We acknowledge the NIH BRS Shared Instrumentation grant S10 RR02485-01 to Temple University for providing funds for purchase of the NMR instrument. J. KENNETH HOOBER spent half a year as visiting professor at the Carlsberg Laboratory.

\section{REFERENCES}

1. ANDERSSON, L., T.C. ISLEY \& R. WOLFENDEN: $\alpha-$ Aminoaldehydes: transition state analogue inhibitors of leucine aminopeptidase. Biochemistry 21, 4177-4180 (1982)

2. Bajkowski, A.S. \& H.C. FrIEdmanN: $\delta$ Aminolevulinic acid formation. Purification and properties of alanine:4,5-dioxolaverate aminotransferase and isolation of 4,5-dioxovalerate from Clostridium tetanomorphum. J. Biol. Chem. 257, 2207-2211 (1982)

3. Brumm,P.J., G.A.Thomas \& H.C. FriedmanN: The role of 4,5-dioxovaleric acid in porphyrin and vitamin $\mathbf{B}_{12}$ formation by clostridia. Biochem. Biophys. Res. Commun. 104, 814-822 (1982)

4. Bruyant, P. \& C.G. Kannangara: Biosynthesis of $\delta$-aminolevulinate in greening barley leaves. VIII: Purification and characterization of the glutamate-tRNA ligase. Carlsberg Res. Commun. 52, 99-109 (1987)

5. Dörnemann, D. \& H. Senger: The synthesis and properties of 4,5-dioxovaleric acid, a possible intermediate in the biosynthesis of 5-aminolevulinic acid, and its in vivo formation in Scenedesmus obliquus. Biochim. Biophys. Acta 628, 35-45 (1980)

6. FLINT, D.H.: Gabaculine inhibits $\delta$-ALA synthesis in chloroplasts. Plant Physiol. 75, suppl. p 170 (1984)

7. FriedmanN, H.C., R. K. Thauer, S.P. Gough \& C.G. KANNANGARA: $\triangle$-Aminolevulinic acid formation in the archaebacterium Methanobacterium thermoautotrophicum requires tRNA. Carlsberg Res. Commun. 52, 363-371 (1987)

8. Houen, G., S.P. Gough \& C.G. Kannangara: $\Delta$ Aminolevulinate synthesis in greening barley. $\mathrm{V}$. The structure of glutamate 1-semialdehyde. Carlsberg Res. Commun. 48, 567-572 (1983)

9. HuANG, D.-D.\& W.-Y. WANG: Chlorophyll biosynthesis in Chlamydomonas starts with the formation of glutamyl-tRNA. J. Biol. Chem. 261, 1345113455 (1986)

10. HuANG, D.-D. \& W.-Y. WANG: Genetic control of chlorophyll biosynthesis: regulation of deltaaminolevulinate synthesis in Chlamydomonas. Mol. Gen. Genet. 205, 217-220 (1986)

11. KAH, A. \& D. DörnEMANN: Glutamic acid-1-semialdehyde, a hypothetical intermediate in the biosynthesis of 5-aminolevulinic acid. Z. Naturforsch. 42C, 209-214 (1987)

12. KahN, A. \& C.G. KanNangara: Gabaculine-resistant mutants of Chlamydomonas reinhardtii with elevated glutamate 1-semialdehyde aminotransferase activity. Carlsberg Res. Commun. 52, 73-81 (1987) 
13. Kannangara, C.G. \& S.P. Gough: Biosynthesis of $\delta$-aminolevulinate in greening barley leaves: Glutamate 1-semialdehyde aminotransferase. Carlsberg Res. Commun. 43, 185-194 (1978)

14. Kannangara, C.G., S.P. Govgh, R.P. Oliver \& S.K. RASMUSSEN: Biosynthesis of $\delta$-aminolevulinate in greening barley leaves VI. Activation of glutamate by ligation to RNA. Carlsberg Res. Commun. 49, 417-437 (1984)

15. Kannangara, C.G. \& A. Schouboe: Biosynthesis of $\delta$-aminolevulinate in greening barley leaves. VII. Glutamate 1-semialdehyde accumulation in gabaculine treated leaves. Carlsberg Res. Commun. 50, 179-191 (1985)

16. KisSel, H.J. \& L. HeIlmeyer, Jr.: Nachweis und Bestimmung von $\gamma, \delta$-dioxovaleriansăure. Reversible Umwandlung von $\gamma, \delta$-dioxovaleriansäure und $\delta$-aminolävulinsaaure in Ratten. Biochim. Biophys. Acta 177, 78-87 (1969)

17. LEWIS, C.A. JR. \& R. WOLFENDEN: Antiproteolytic aldehydes and ketones: substituent and secondary deuterium isotope effects on equilibrium addition of water and other nucleophiles. Biochemistry 16 , 4886-4890 (1977)

18. LOWRY, O.H., N.J. Rosebrough, A.L. FarR \& R.J RANDALL: Protein measurement with the Folin phenol reagent. J. Biol. Chem. 193, 265-275 (1951)

19. MAU, Y.-H., W.-Y. WANG, R.N. TAMURA \& T.-E. CHANG: Identification of an intermediate of $\delta$ aminolevulinate biosynthesis in Chlamydomonas by high-performance liquid chromatography. Arch. Biochem. Biophys. 255, 75-79 (1987)

20. MaUzerall, D. \& S. Granick: The occurrence and determination of $\delta$-aminolevulinic acid and porphobilinogen in urine. J. Biol. Chem. 219, 435-446 (1956)

21. MaYer, S.M.. S.I. Beale \& J.D. Weinstein: Enzymatic conversion of glutamate to $\delta$-aminolevulinic acid in soluble extracts of Euglena gracilis. J. Biol. Chem. 262, 12541-12549 (1987)

22. MeISCH,H.-U.,H. HoffMANN \& W. Reinle: Biosynthesis of chlorophyll precursors in green algae. Purification and characterization of L-glutamate:4,5-dioxovaleric acid aminotransferase from Chlorella fusca. Biochim. Biophys. Acta 743, 281 289 (1983)

23. MeISCH,H.-U. \& R. Maus: Studies on the synthesis and biological significance of glutamate-1-semialdehyde as a precursor of chlorophylls. Z. Naturforsch. 38C, 563-570 (1983)

24. RANDO, R.R.: Mechanism of the irreversible inhibition of $\gamma$-aminobutyric acid: $\alpha$-ketoglutaric acid transaminase by the neurotoxin gabaculine. Biochemistry 16, 4604-4610 (1977)

25. SaWicki, E., T.R. Hauser, T.W. Stanley \& W. ElBERT: The 3-methyl-2-benzothiazolone hydrazone test. Sensitive new methods for the detection, rapid estimation, and determination of aliphatic aldehydes. Anal. Chem. 33, 93-96 (1961)

26. Schön, A.. G. Krupp, S. Gough, S. Berry-Lowe, C.G. KanNangara \& D. Söll: The RNA required in the first step of chlorophyll biosynthesis is a chloroplast glutamate tRNA. Nature (London) 322, 281-284 (1986)

27. Shibata, H. \& H. Ochial: Purification and properties of $\delta$-aminolevulinic acid dehydratase from radish cotyledons. Plant Cell Physiol. 18, 421-429 (1977)

28. SHIOI, Y., M. DOI \& T. SASA: Purification and characterization of L-alanine:4,5-dioxovalerate (glyoxylate) aminotransferase from radish (Raphanus sativus L.) seedlings. Plant Cell Physiol. 25, 14871493 (1984)

29. SOPER. T.S. \& J.M. MANNING: Inactivation of pyridoxal phosphate enzymes by gabaculine. Correlation with enzymatic exchange of $\beta$-protons. J. Biol. Chem. 257, 13930-13936 (1982)

30. WanG, W.-Y., S.P. Gough \& C.G. Kannangara: Biosynthesis of $\delta$-aminolevulinate in greening barley leaves. IV. Isolation of three soluble enzymes required for the conversion of glutamate to $\delta$ aminolevulinate. Carlsberg Res. Commun. 46, 243-257 (1981)

31. WEINSTEIN, J.D. \& S.I. BEALE: RNA is required for enzymatic conversion of glutamate to $\delta$ aminolevulinate by extracts of Chlorella vulgaris. Arch. Biochem. Biophys. 239, 87-93 (1985)

32. WeINSTEIN, J.D., S.M. MAYER \& S.I. BEALE: Formation of $\delta$-aminolevulinic acid from glutamic acid in algal extracts. Separation into an RNA and three required enzyme components by serial affinity chromotography. Plant Physiol. 84, 244-250 (1987) 